\title{
CHARAKTERYSTYKA SYSTEMÓW ZARZĄDZANIA RYZYKIEM STOSOWANYCH PRZEZ NAJWIĘKSZE SPÓŁKI GIEŁDOWE W POLSCE
}

\author{
Sylwia Przetacznik \\ AGH Akademia Górniczo-Hutnicza \\ Wydział Zarządzania
}

\begin{abstract}
Streszczenie: Artykuł prezentuje wyniki przeprowadzonej przez autorkę analizy systemów zarządzania ryzykiem stosowanych przez największe, polskie spółki giełdowe, ze szczególnym uwzględnieniem przedsiębiorstw posiadających wdrożone systemy zintegrowanego zarządzania ryzykiem (ERM). Badania zostały przeprowadzone na podstawie analizy informacji dotyczących zarządzania ryzykiem, publikowanych przez spółki należące do indeksów WIG20 oraz mWIG40 w raportach rocznych za rok 2015 i zostały podzielone na dwa etapy. Etap pierwszy polegał na ogólnej analizie sprawozdań finansowych i sprawozdań z działalności wybranych spółek. Miało to na celu określenie stopnia dojrzałości prezentowanych przez te przedsiębiorstwa podejść do zarządzania ryzykiem. $\mathrm{Na}$ tej podstawie zostały wyodrębnione dwie grupy: spółki mające wdrożone systemy ERM oraz przedsiębiorstwa zarządzające ryzykiem w sposób tradycyjny (silosowy). Etap drugi polegał na szczegółowej analizie informacji publikowanych przez firmy posiadające systemy zintegrowanego zarządzania ryzykiem, w celu porównania cech systemów analizowanych z określonymi wcześniej cechami, jakie powinny posiadać systemy ERM.
\end{abstract}

Słowa kluczowe: ERM, niepewność, ryzyko, system zarządzania ryzykiem, zintegrowane zarządzanie ryzykiem

DOI: $10.17512 /$ znpcz.2017.4.2.04

\section{Wprowadzenie}

Ryzyko jest nieodłącznym elementem działalności każdego podmiotu i towarzyszy każdej podejmowanej decyzji biznesowej. Zmiany otoczenia, na jakie narażone są obecnie przedsiębiorstwa, oraz rosnący stopień skomplikowania gospodarki powodują, że świadomość ryzyka oraz zarządzanie nim staje się aktualnie koniecznością. Ekonomiczne konsekwencje podejmowanych decyzji i ich waga jednoznacznie podnoszą rangę badań nad ryzykiem (Suchecka, Nieszporska 2015, s. 103).

Zarządzanie ryzykiem stanowi kluczową umiejętność, bez której nie da się zbudować przewagi konkurencyjnej. Na kształt systemu zarządzania ryzykiem stosowanego $\mathrm{w}$ danym przedsiębiorstwie wpływa wiele czynników, m.in. postawa menedżerów, znaczenie ryzyka dla danej działalności czy charakter organizacji. W zależności od przyjętych kryteriów można dokonać wielu klasyfikacji podejść do zarządzania ryzykiem, jednak najbardziej znany jest podział na tradycyjne (silosowe) i zintegrowane zarządzanie ryzykiem (Enterprise Risk Management - ERM) 
(Malinowska 2011, s. 63-67). Zgodnie z podejściem tradycyjnym poszczególne ryzyka traktowane są oddzielnie i niezależnie, natomiast według koncepcji ERM konieczne jest zarządzanie wszystkimi ryzykami, na jakie narażone jest przedsiębiorstwo, biorąc pod uwagę powiązania, jakie mogą występować między poszczególnymi ryzykami, oraz uwzględniając wpływ zarządzania ryzykiem na strategię organizacji (Bromiley i in. 2015, s. 265-266). Relatywnie nowa koncepcja ERM uważana jest za bardziej efektywną i przynoszącą lepsze rezultaty w porównaniu z podejściem tradycyjnym (Sasin 2011, s. 99; Lam 2014, s. 51-52).

Systemy zarządzania ryzykiem stosowane przez polskie przedsiębiorstwa charakteryzują się dużą różnorodnością i różnym stopniem dojrzałości. Wciąż stosunkowo niewiele polskich spółek wdrożyło nowoczesne systemy zintegrowanego zarządzania ryzykiem, a większość $\mathrm{z}$ nich zarządza tylko niektórymi rodzajami ryzyka, ignorując przy tym pozostałe zagrożenia związane z prowadzoną działalnością (Kasiewicz, Kurliński, Świerżewski 2011; Kasiewicz 2011, s. 154-171; Aon Polska 2013, s. 19).

Celem niniejszej publikacji jest przedstawienie wyników analizy systemów zarządzania ryzykiem stosowanych przez największe spółki notowane na GPW, ze szczególnym uwzględnieniem przedsiębiorstw posiadających systemy zintegrowanego zarządzania ryzykiem (ERM), a także porównanie głównych cech, jakie powinny posiadać systemy ERM, z cechami systemów analizowanych. Przedstawione wyniki badań pozwolą na ocenę stopnia dojrzałości systemów zarządzania ryzykiem stosowanych przez badane przedsiębiorstwa. Badania zostały przeprowadzone na podstawie analizy informacji dotyczących zarządzania ryzykiem, publikowanych przez spółki należące do indeksów WIG20 oraz mWIG40 w raportach rocznych za rok 2015.

\section{Czym jest zintegrowane zarządzanie ryzykiem?}

Postawy wobec ekspozycji przedsiębiorstw na ryzyko ulegały na przestrzeni lat znacznej ewolucji. Najstarsze, pasywne podejście do ryzyka zakładało brak możliwości zarządzania ryzykiem. Za nieco bardziej doskonałą można uznać postawę reaktywną, polegającą na tym, że reakcja na ryzyko występuje dopiero po ujawnieniu negatywnych skutków danego ryzyka. Współcześnie najczęściej spotykana wśród polskich przedsiębiorstw jest postawa aktywna, czyli tradycyjne zarządzanie ryzykiem. Najbardziej doskonała postawa proaktywna, mimo że w ostatnich latach zyskuje na popularności, w dalszym ciągu jest dość rzadko spotykana wśród polskich przedsiębiorstw (Adamska 2009, s. 15-16).

Cechy charakterystyczne tradycyjnego, silosowego podejścia do zarządzania ryzykiem to przede wszystkim zarządzanie pojedynczymi rodzajami ryzyka w organizacji w sposób niezależny i wybiórczy. Osoby odpowiedzialne za poszczególne rodzaje ryzyka mają za zadanie dążenie do ograniczania konkretnych zagrożeń (ryzyko widziane tylko jako zjawisko negatywne), działając przy tym w izolacji oraz nie biorąc pod uwagę powiązań, jakie mogą zachodzić między poszczególnymi ryzykami (Malinowska 2011, s. 67-68). Podejście tradycyjne nie uwzględnia ponadto wpływu ryzyka na cele i strategię organizacji, skupiając się 
przy tym jedynie na pojedynczych, najbardziej znanych rodzajach ryzyka (Krysiak 2011, s. 1). Zupełnie inne podejście prezentuje nowoczesna koncepcja zintegrowanego zarządzania ryzykiem. ERM jest uznawane za najlepszą metodę zapewnienia wydajności zasobów przedsiębiorstwa oraz bardzo efektywny sposób na optymalizację relacji ryzyko-zyskowność w przedsiębiorstwie (Sasin 2011, s. 99). Poniższy rysunek (Rysunek 1) przedstawia ewolucję postaw wobec ryzyka, zaczynając od najwcześniejszej, najmniej doskonałej, a kończąc na nowoczesnym, zintegrowanym podejściu do zarządzania ryzykiem:

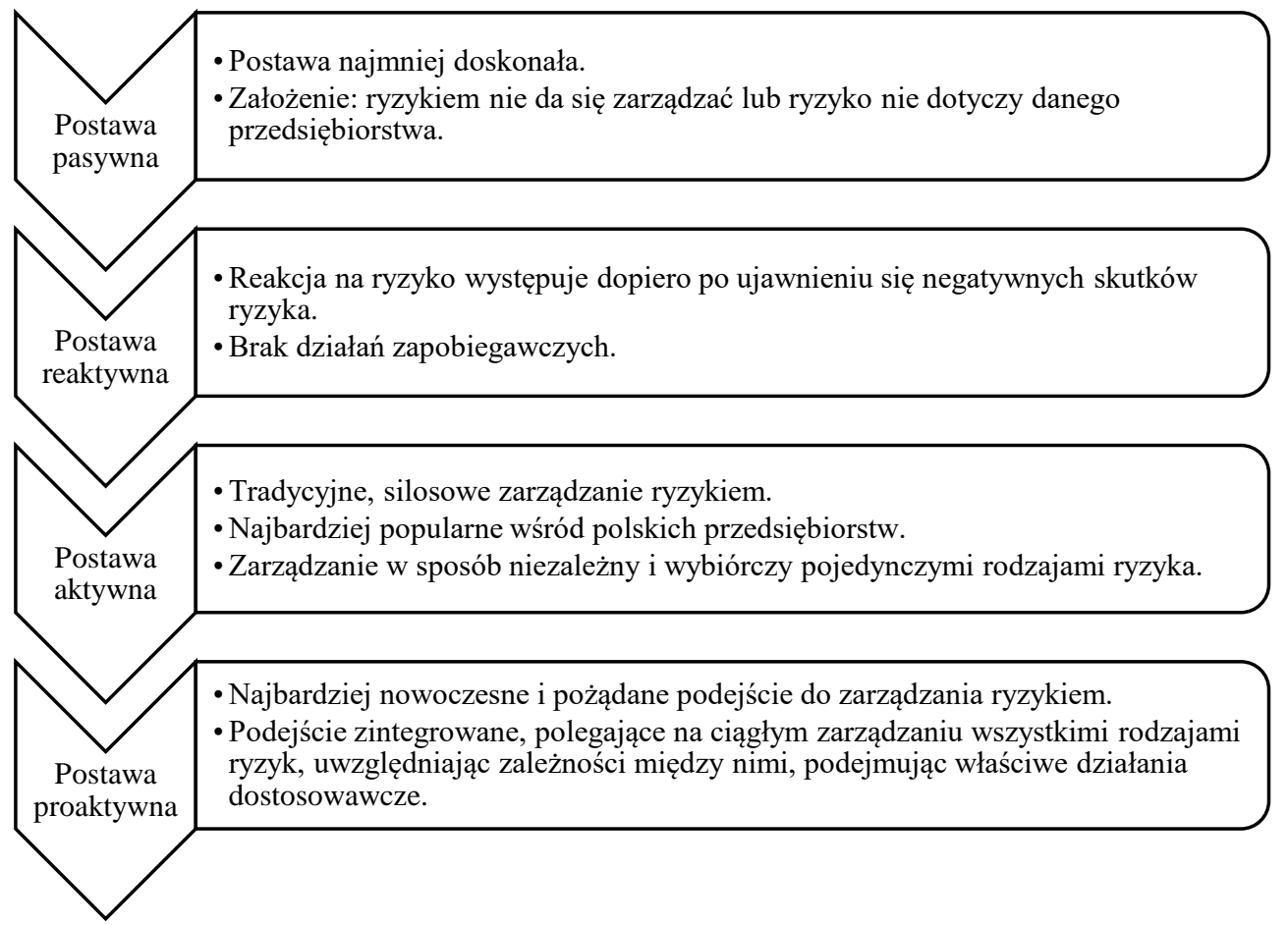

\section{Rysunek 1. Ewolucja podejścia do ryzyka}

Źródło: Opracowanie własne na podstawie (Adamska 2009, s. 15-16)

Koncepcja zintegrowanego zarządzania ryzykiem pozwala na połączenie zarządzania ryzykiem ze wszystkimi procesami zarządzania przedsiębiorstwem (Korombel 2013, s. 47). W przeciwieństwie do tradycyjnych koncepcji zarządzania ryzykiem w przypadku filozofii ERM ryzyko traktowane jest w sposób holistyczny, czyli całościowy i wieloaspektowy, a jego istotą jest kompleksowość podejścia do ryzyka. Oznacza to, że w koncepcji tej podkreślana jest konieczność rozpatrywania różnych rodzajów ryzyka występujących w organizacji, biorąc przy tym pod uwagę współzależności mające miejsce między poszczególnymi ryzykami oraz obejmując ochroną wszystkie zasoby przedsiębiorstwa - zarówno materialne i finansowe, jak i niematerialne (Malinowska 2011, s. 69). Zarządzając ryzykiem, należy brać pod uwagę nie tylko jego negatywne aspekty, lecz warto również roz- 
ważyć potencjalne ryzyka pozytywne (szanse) i podjąć odpowiednie działania w celu zwiększenia prawdopodobieństwa ich wykorzystania. W przypadku koncepcji ERM bardzo istotny jest również właściwy dobór ludzi oraz stworzenie sprzyjającej kultury organizacyjnej (Lam 2014, s. 4). Z uwagi na silny związek między ryzykami a realizowaniem celów strategicznych organizacji zarządzanie ryzykiem powinno być częścią planowania strategicznego (Monahan 2008, s. 13). Zgodnie $\mathrm{z}$ definicją zawartą $\mathrm{w}$ jednym $\mathrm{z}$ najbardziej popularnych standardów zarządzania ryzykiem COSO II - ERM to realizowany przez zarząd, kierownictwo oraz pozostały personel przedsiębiorstwa, uwzględniony $\mathrm{w}$ strategii $\mathrm{i} \mathrm{w}$ całym przedsiębiorstwie proces, którego celem jest identyfikacja potencjalnych zdarzeń mogących wywrzeć wpływ na przedsiębiorstwo, utrzymywanie ryzyka w ustalonych granicach oraz rozsądne zapewnienie realizacji celów organizacji (COSO 2004, s. 3). Standard ten podkreśla ciągłość i cykliczność procesu zarządzania ryzykiem oraz wyróżnia poszczególne etapy tego procesu (ustalenie celów, identyfikacja wydarzeń, ocena ryzyka, reakcja na ryzyko, czynności kontrolne). Bardzo zbliżone podejście do zarządzania ryzykiem zostało przedstawione w innym popularnym standardzie zarządzania ryzykiem - ISO 31000. ERM zostało w nim zdefiniowane jako skoordynowane działania dotyczące kierowania i nadzorowania organizacją w odniesieniu do ryzyka (ISO/IEC 31010:2009, s. 6). Zgodnie z normą ISO zarządzanie ryzykiem powinno należeć do obowiązków zarządu i być integralną częścią wszystkich procesów występujących w organizacji. Powinno być ponadto przejrzyste, całościowe, dynamiczne, a także dopasowane do organizacji (ISO Guide 73:2009). Istotną cechą systemów zintegrowanego zarządzania ryzykiem jest fakt, iż ERM należy do systemów scentralizowanych, co wiąże się z koniecznością określenia nadrzędnej roli zarządu w zakresie zarządzania ryzykiem oraz powołania osoby odpowiedzialnej za koordynowanie i nadzorowanie działań związanych z zarządzaniem ryzykiem w organizacji (menedżera ds. ryzyka). Bardzo ważne jest ponadto odpowiednie współdziałanie wszystkich komórek organizacyjnych przedsiębiorstwa oraz prawidłowa komunikacja między pracownik -ami, z uwzględnieniem pracowników najniższego szczebla w danej organizacji (Malinowska 2011, s. 70).

Podsumowując, zintegrowane zarządzanie ryzykiem to nowoczesne, holistyczne podejście do zarządzania ryzykiem. Poszczególne opracowania dotyczące koncepcji ERM nieznacznie różnią się między sobą, głównie w sposobie podejścia, zakresie i umiejscowieniu procesów zarządzania oraz w szczegółach technicznych. Mimo tego autorzy są zgodni co do ogólnych celów i założeń, a także metod i technik stosowanych w nowoczesnym zarządzaniu ryzykiem (Sasin 2011, s. 99). $\mathrm{Na}$ podstawie powyższej analizy koncepcji zintegrowanego zarządzania ryzykiem można wyróżnić następujące najistotniejsze cechy charakteryzujące podejście ERM:

- zarządzanie ryzykiem, jako ciągły, powtarzalny proces, składający się ze ściśle określonych, następujących po sobie etapów;

- proces realizowany w całym przedsiębiorstwie;

- zaangażowanie w zarządzanie ryzykiem wszystkich pracowników, na każdym szczeblu organizacji (odpowiednia kultura organizacyjna); 
- odpowiedzialność zarządu za zarządzanie ryzykiem;

- zarządzanie ryzykiem uwzględnione w strategii;

- identyfikowanie i zarządzanie wszystkimi rodzajami ryzyk;

- ryzyko widziane nie tylko jako zagrożenie, ale również jako szansa;

- funkcjonowanie osoby odpowiedzialnej za koordynowanie i nadzorowanie działań związanych z zarządzaniem ryzykiem w organizacji (menedżera ds. ryzyka / risk managera).

Wymienione powyżej cechy charakterystyczne systemów zintegrowanego zarządzania ryzykiem zostały wykorzystane przy analizie jakości systemów zarządzania ryzykiem stosowanych przez największe spółki giełdowe notowane na GPW, co zostało opisane w dalszej części artykułu.

\section{Cel podjętych badań}

Tematyka zarządzania ryzykiem w przedsiębiorstwie staje się coraz bardziej popularna nie tylko w polskiej i zagranicznej literaturze, ale również w praktyce gospodarczej. Co więcej, zgodnie z zaleceniami Rady Giełdy, wszystkie spółki notowane na GPW mają obowiązek utrzymywania w swoich strukturach skutecznych systemów: kontroli wewnętrznej, zarządzania ryzykiem oraz nadzoru zgodności działalności z prawem (compliance), a także skuteczną funkcję audytu wewnętrznego, odpowiednie do wielkości spółki i rodzaju oraz skali prowadzonej działalności (GPW 2016). W związku z tym spółki giełdowe powinny charakteryzować się wysoką świadomością ryzyka i konieczności zarządzania nim oraz znacznym stopniem zaawansowania stosowanych systemów zarządzania ryzykiem. Mimo tego nawet wśród największych polskich spółek giełdowych można zauważyć sporą różnorodność oraz istotne różnice w stopniu dojrzałości prezentowanych postaw wobec ryzyka, a co za tym idzie również w stosowanych przez te przedsiębiorstwa systemach zarządzania ryzykiem.

$\mathrm{Na}$ istotne zróżnicowanie oraz zaskakująco niski poziom dojrzałości prezentowanych podejść do ryzyka i zarządzania nim wśród polskich przedsiębiorstw wskazują dotychczasowe badania. Badania ankietowe przeprowadzone w 2010 roku na grupie 124 menedżerów (Kasiewicz, Kurliński, Świerżewski 2011) pokazują, że jedynie $15 \%$ ankietowanych firm stosuje proaktywne podejście do zarządzania ryzykiem, uznając zarządzanie ryzykiem za umiejętność strategiczną. Jest to mniejszy odsetek niż w przypadku przedsiębiorstw nie podejmujących działań w zakresie zarządzania ryzykiem, prezentujących postawę reaktywną (18\% respondentów). W przytoczonych badaniach największą grupę stanowią przedsiębiorstwa, w których zarządzanie ryzykiem polega jedynie na monitoringu i kontroli czynników ryzyka (41\% odpowiedzi). Inne badania, przeprowadzone w 2013 roku przez firmę Aon (Aon Polska 2013, s. 19), przedstawiają poziom zaawansowania i dojrzałości procesu zarządzania ryzykiem wśród badanych organizacji. Na podstawie badań ankietowych poziom zaawansowania ponad $28 \%$ badanych przedsiębiorstw określono jako początkowy lub podstawowy (oceny od 1 do 2 w skali 1-5). $\mathrm{Z}$ drugiej strony tylko niecałe $15 \%$ firm oceniono na poziomie operacyjnym lub zaawansowanym (oceny od 4 do 5). Warto również wspomnieć o wynikach badań 
analizowanych przez S. Kasiewicza (Kasiewicz 2011, s. 154-171). Na podstawie dziewięciu niezależnych badań przeprowadzonych przez różnych badaczy w latach 2004-2009 wywnioskował on, iż „poziom dojrzałości zarządzania ryzykiem w polskich przedsiębiorstwach jest wyjątkowo niski i przejście na model zintegrowany wg koncepcji ERM jest mało realne w perspektywie co najmniej kilku najbliższych lat”. S. Kasiewicz określił dominującą wśród polskich przedsiębiorstw postawę wobec ryzyka jako reaktywną, podkreślając fakt, że „w krajowych firmach nie zarządza się ryzykiem, a jedynie zaistniałym kryzysem” (Kasiewicz 2011, s. 166).

Wyniki przytoczonych powyżej badań wyraźnie wskazują, iż poziom zaawansowania systemów zarządzania ryzykiem $\mathrm{w}$ badanych organizacjach był raczej niski, choć między analizowanymi przedsiębiorstwami wystąpiło duże zróżnicowanie w prezentowanym podejściu do ryzyka. Warto jednak zauważyć, że wśród polskich przedsiębiorstw świadomość potrzeby zarządzania ryzykiem stopniowo rośnie i w kolejnych latach coraz więcej spółek decyduje się na wdrażanie nowoczesnych systemów zarządzania ryzykiem. Co więcej, popularność i stopień zaawansowania wdrażanych systemów zarządzania ryzykiem są zależne między innymi od branży, w jakiej działa dane przedsiębiorstwo, oraz od wielkości danej firmy. Badania przeprowadzone przez autorkę mają na celu analizę bieżącej sytuacji w zakresie systemów zarządzania ryzykiem stosowanych przez największe polskie spółki giełdowe. Celem podjętych badań jest określenie stopnia dojrzałości prezentowanych przez analizowane firmy podejść do zarządzania ryzykiem, ze szczególnym uwzględnieniem przedsiębiorstw stosujących zintegrowane zarządzanie ryzykiem. Istotnym elementem badań jest ponadto porównanie najważniejszych cech, jakie powinny posiadać systemy zintegrowanego zarządzania ryzykiem $\mathrm{z}$ cechami systemów stosowanych $\mathrm{w}$ analizowanych przedsiębiorstwach.

\section{Zakres i metoda badań}

Sprawozdanie finansowe to jedno $\mathrm{z}$ głównych narzędzi komunikacji między spółką a jej otoczeniem. Powinno być więc sporządzone rzetelnie i zawierać wszystkie istotne informacje dotyczące funkcjonowania przedsiębiorstwa, w tym dotyczące stosowanych zasad zarządzania ryzykiem. Publikowanie informacji dotyczących systemów zarządzania ryzykiem wpływa pozytywnie na wizerunek przedsiębiorstwa, w związku z czym spółki chętnie i często dość szczegółowo opisują w sprawozdaniach finansowych zasady zarządzania ryzykiem w swoich organizacjach.

Przeprowadzone badania polegały na szczegółowej analizie informacji dotyczących zarządzania ryzykiem publikowanych $\mathrm{w}$ rocznych sprawozdaniach finansowych oraz sprawozdaniach z działalności na koniec 2015 roku. Grupa badawcza to 20 spółek notowanych $\mathrm{w}$ indeksie WIG20 oraz 40 spółek z indeksu mWIG40 łącznie 60 przedsiębiorstw. Wybrane spółki to największe polskie przedsiębiorstwa, dysponujące dużym kapitałem oraz wykwalifikowanymi pracownikami, a zatem mające możliwości wdrażania zaawansowanych systemów zarządzania. Spółki giełdowe są ponadto zobligowane do utrzymywania skutecznych systemów 
zarządzania ryzykiem. Wybrana grupa badawcza powinna być więc najbardziej nowoczesna i zaawansowana, jeśli chodzi o stosowane systemy zarządzania, w tym zarządzania ryzykiem, powinna być w tym zakresie przykładem dla innych przedsiębiorstw.

Przeprowadzane badanie zostało podzielone na dwa etapy. Etap pierwszy polegał na ogólnej analizie sprawozdań finansowych i sprawozdań z działalności wybranych spółek. Miało to na celu określenie stopnia dojrzałości prezentowanych przez te przedsiębiorstwa podejść do zarządzania ryzykiem oraz wybór spółek posiadających wdrożone systemy zintegrowanego zarządzania ryzykiem. Etap drugi polegał na szczegółowej analizie informacji publikowanych przez firmy posiadające ERM w celu porównania cech systemów analizowanych z określonymi wcześniej cechami, jakie powinny posiadać nowoczesne systemy ERM.

Cechy systemów zintegrowanego zarządzania ryzykiem, jakie zostały wybrane do badania, zostały zdefiniowane na podstawie dostępnej literatury oraz istniejących standardów zarządzania ryzykiem i są to cechy opisane w części Czym jest zintegrowane zarządzanie ryzykiem? niniejszej publikacji. Wytypowane własności to najważniejsze, uniwersalne cechy, jakimi powinien charakteryzować się każdy nowoczesny system zintegrowanego zarządzania ryzykiem. Cechy systemów zarządzania ryzykiem opisywane przez każdą z badanych spółek zostały porównane z każdą z wyżej wymienionych cech.

\section{Wyniki przeprowadzonych badań}

Na podstawie przeprowadzonej analizy można stwierdzić, że wszystkie badane spółki zarządzają ryzykiem. Spośród analizowanych przedsiębiorstw zostały wyodrębnione dwie grupy: spółki mające wdrożone systemy ERM oraz przedsiębiorstwa zarządzające ryzykiem w sposób tradycyjny (silosowy). Udział procentowy przedsiębiorstw stosujących ERM oraz tradycyjne zarządzanie ryzykiem widoczny jest na poniższym wykresie (Rysunek 2).

Spośród spółek z indeksu WIG20 75\% (15 spółek) publikuje informacje o stosowaniu nowoczesnych systemów zintegrowanego zarządzania ryzykiem, a pozostałe $25 \%$ (5 spółek) zarządza ryzykiem w sposób tradycyjny. Wśród przedsiębiorstw z indeksu mWIG40 udział ten wynosi odpowiednio 30\% (12 spółek) stosujących ERM oraz 70\% (28 spółek) tradycyjnie zarządzających ryzykiem.

W przypadku grupy przedsiębiorstw stosujących metody tradycyjne główne obszary zarządzania ryzykiem koncentrują się przede wszystkim wokół ryzyk finansowych (ryzyko płynności, kredytowe, rynkowe, walutowe itp.) oraz ryzyk zgodności (ryzyka prawne, regulacyjne, związane $\mathrm{z}$ ładem korporacyjnym itp.). Przedsiębiorstwa te nie uwzględniają wszystkich zagrożeń, na jakie są narażone, oraz nie biorą pod uwagę zależności, jakie mogą występować pomiędzy ryzykami. Zarządzanie ryzykiem nie jest traktowane jako część strategii tych przedsiębiorstw, a jedynie jako odrębna, pojedyncza funkcja, mająca na celu minimalizowanie strat mogących wystąpić w wybranych obszarach związanych z działalnością. Przedsiębiorstwa te prezentują aktywną postawę wobec ryzyka. 


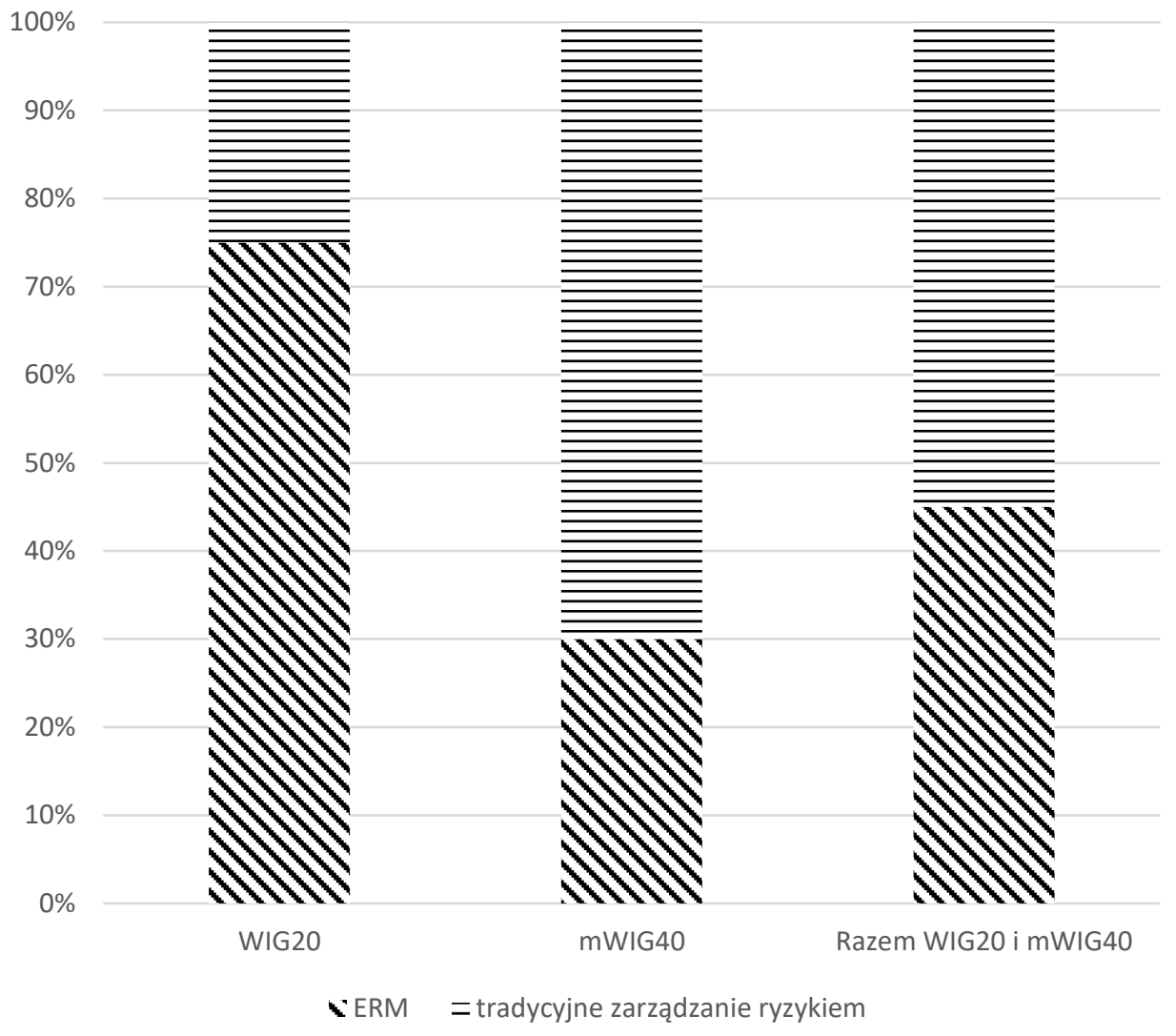

Rysunek 2. Zarządzane ryzykiem w sprawozdaniach największych spółek notowanych na GPW

Źródło: Opracowanie własne

Biorąc pod uwagę grupę przedsiębiorstw stosujących systemy zintegrowanego zarządzania ryzykiem, można zauważyć dużą różnorodność, jeśli chodzi o przyjęte zasady oraz podstawowe cechy wdrożonych systemów. Do badania zostały wybrane ogólne i uniwersalne cechy ERM, można zatem przyjąć, że każde z przedsiębiorstw mających wdrożony nowoczesny system zarządzania ryzykiem powinno stosować wszystkie poniższe reguły. W praktyce nie wszystkie wymienione cechy były uwzględniane w opisywanych przez spółki zasadach zarządzania ryzykiem. Poniższy wykres (Rysunek 3) przedstawia wyniki porównania wybranych cech, jakimi powinny charakteryzować się systemy zintegrowanego zarządzania ryzykiem, z cechami systemów ERM w analizowanych przedsiębiorstwach. Wyniki dotyczą grupy przedsiębiorstw z WIG20 i mWIG40 stosujących systemy ERM łącznie 27 spółek. 


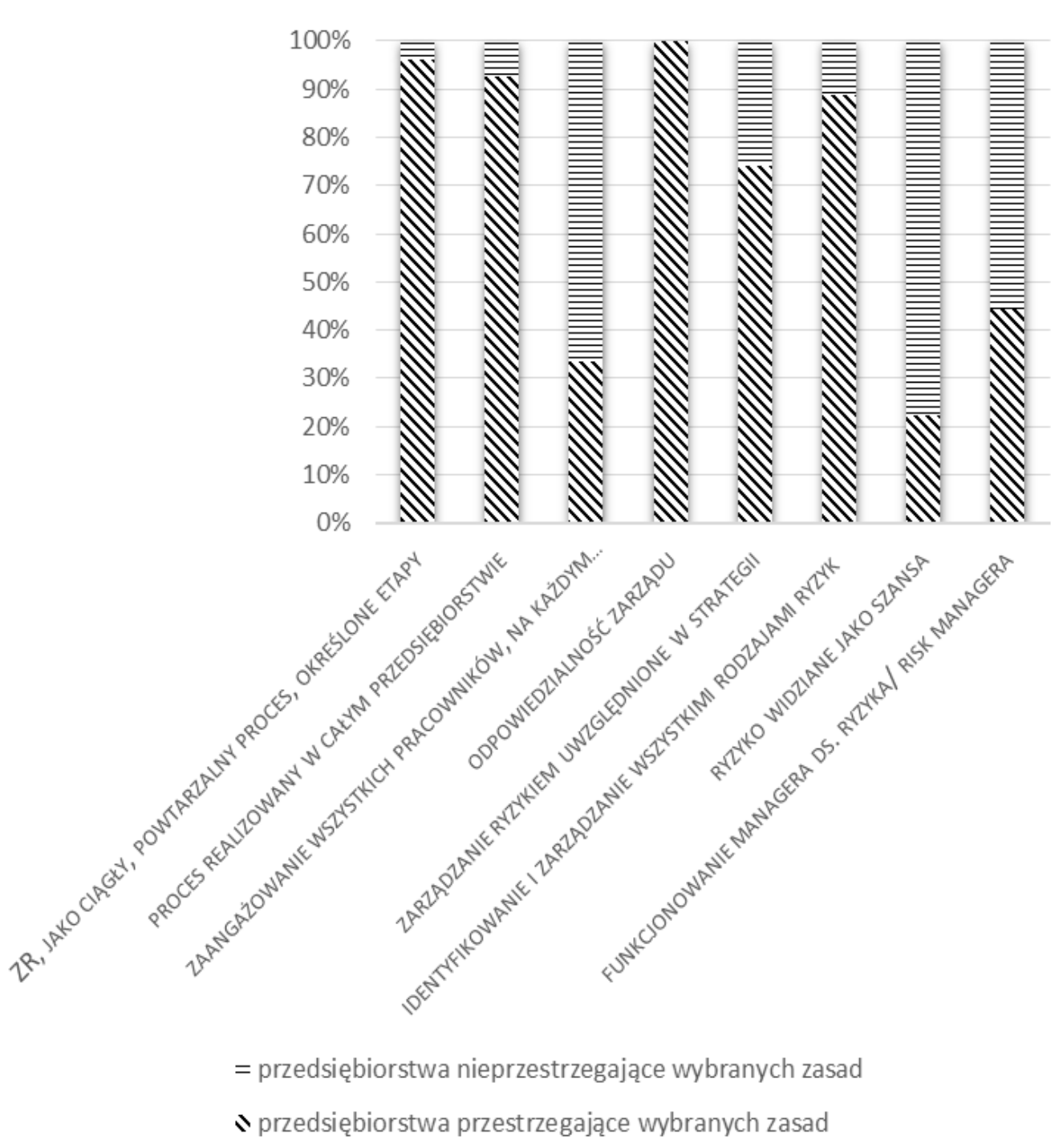

Rysunek 3. Porównanie cech, jakie powinny posiadać systemy ERM z cechami systemów analizowanych

Źródło: Opracowanie własne

Jedyną badaną cechą, która występuje w przypadku wszystkich analizowanych przedsiębiorstw, jest odpowiedzialność zarządu za zarządzanie ryzykiem. Nieznacznie gorsze wyniki uzyskały:

- Zarządzanie ryzykiem, jako ciągły, powtarzalny proces, składający się ze ściśle określonych, następujących po sobie etapów - cecha została zidentyfikowana aż w 96\% badanych spółek. 
- Proces realizowany w całym przedsiębiorstwie - 93\% przedsiębiorstw przestrzega tej zasady, w przypadku pozostałych $7 \%$ cecha nie została zidentyfikowana.

- Identyfikowanie i zarządzanie wszystkimi rodzajami ryzyk - w przypadku 89\% spółek zasada ta została uwzględniona, pozostałe spółki zarządzają tylko wybraną grupą ryzyk.

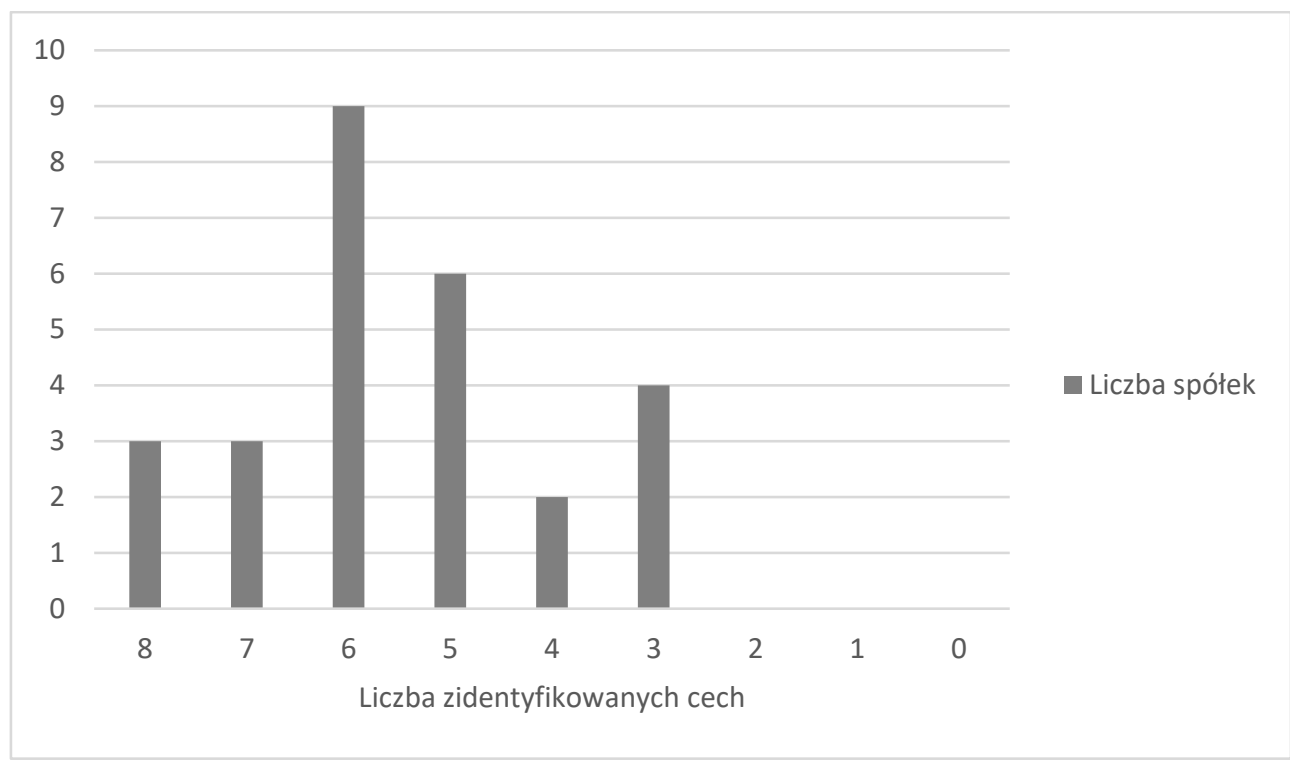

\section{Rysunek 4. Liczba zidentyfikowanych cech systemów ERM w grupie badanych przedsiębiorstw}

Źródło: Opracowanie własne

Przeprowadzona analiza pozwoliła również na identyfikację zasad stosowanych najrzadziej w przypadku analizowanych spółek, będących równocześnie obszarami, na które przedsiębiorstwa powinny kłaść w przyszłości większy nacisk. Cechy, które zostały zidentyfikowane w najmniejszej liczbie badanych przedsiębiorstw, to:

- Ryzyko widziane nie tylko jako zagrożenie, ale również jako szansa -znacząca większość, bo aż 78\% badanych przedsiębiorstw postrzega ryzyko jedynie jako zagrożenie, nie uwzględniając przy tym mogących wystąpić ryzyk pozytywnych. Takie podejście ogranicza możliwość czerpania pełnych korzyści, jakie może przynieść przedsiębiorstwu wdrożenie systemu zarządzania ryzykiem.

- Zaangażowanie w zarządzanie ryzykiem wszystkich pracowników, na każdym szczeblu organizacji (odpowiednia kultura organizacyjna) - aż 67\% badanych spółek nie angażuje w zarządzanie ryzykiem całego zespołu. Pracownicy nie są świadomi konieczności uczestniczenia w procesie zarządzania ryzykiem (jest to istotne zwłaszcza na etapie identyfikacji oraz reakcji na ryzyka).

- Funkcjonowanie osoby odpowiedzialnej za koordynowanie i nadzorowanie działań związanych z zarządzaniem ryzykiem w organizacji (menedżera ds. ry- 
zyka / risk managera) - w 56\% badanych przedsiębiorstw nie istnieje stanowisko menedżera ryzyka, zostało ono zidentyfikowane tylko w $44 \%$ badanych spółek.

- Zarządzanie ryzykiem uwzględnione w strategii - tylko w 74\% badanych przedsiębiorstw zarządzanie ryzykiem jest częścią zarządzania strategicznego.

- Obok analizy częstości występowania poszczególnych cech wyniki uzyskane $\mathrm{w}$ badaniu zostały również przedstawione $\mathrm{w}$ odniesieniu do badanych przedsiębiorstw. Liczba zidentyfikowanych cech została podsumowana dla każdej z badanych spółek oddzielnie, następnie otrzymane wyniki zostały zsumowane, z wzięciem pod uwagę liczby zidentyfikowanych cech w poszczególnych spółkach. Wyniki zostały zaprezentowane na powyższym wykresie (Rysunek 4).

Jedynie $w$ trzech badanych przedsiębiorstwach zostały zidentyfikowane wszystkie badane cechy systemów zarządzania ryzykiem. W przypadku żadnej $\mathrm{z}$ analizowanych spółek nie wystąpiły mniej niż trzy cechy, jednak biorąc pod uwagę, że w badaniu zostały uwzględnione jedynie podstawowe, uniwersalne założenia nowoczesnej koncepcji ERM, wyniki niższe niż połowa zidentyfikowanych cech w danym przedsiębiorstwie można uznać za słabe. W przypadku przedsiębiorstw z najmniejszą liczbą rozpoznanych cech stosowane systemy zarządzania ryzykiem nie spełniają większości podstawowych założeń koncepcji ERM, co może świadczyć o niskiej jakości i efektywności funkcjonowania tych systemów w omawianych spółkach.

\section{Podsumowanie}

Wybrana grupa badawcza to największe polskie spółki publiczne, notowane w indeksach WIG20 i mWIG40. Jest to zatem grupa przedsiębiorstw, która powinna być wiodąca we wdrażaniu nowoczesnych rozwiązań, również w zakresie zarządzania ryzykiem. Mimo tego tylko $45 \%$ badanych spółek deklaruje stosowanie systemów ERM. W przypadku pozostałych $55 \%$ prezentowana jest aktywna postawa wobec ryzyka, charakterystyczna dla tradycyjnego, silosowego podejścia do zarządzania ryzykiem w organizacji. Co więcej, w przypadku części przedsiębiorstw deklarujących stosowanie ERM, opisywane systemy nie spełniają większości podstawowych założeń koncepcji zintegrowanego zarządzania ryzykiem.

Biorąc pod uwagę analizowane cechy systemów ERM, zasady najczęściej przestrzegane wśród badanych przedsiębiorstw to odpowiedzialność zarządu za zarządzanie ryzykiem oraz ciągły, powtarzalny proces zarządzania ryzykiem. Z kolei cechy stosowane najrzadziej, z którymi badane spółki mają największy problem, to uwzględnianie ryzyk pozytywnych, zaangażowanie $\mathrm{w}$ zarządzanie ryzykiem wszystkich pracowników, a także funkcjonowanie menedżera ds. ryzyka w badanych spółkach.

Na podstawie dokonanych badań można wywnioskować, że polskie spółki giełdowe charakteryzują się dużą różnorodnością stopnia dojrzałości systemów zarządzania ryzykiem. Przeprowadzona analiza wskazuje na bardzo wysoką świadomość ryzyka wśród grupy przedsiębiorstw, które uzyskały największą liczbę zidentyfikowanych cech charakterystycznych dla podejścia ERM. Równocześnie 
jednak w przypadku większości analizowanych przedsiębiorstw świadomość zarządzania ryzykiem, a co za tym idzie dojrzałość stosowanych systemów zarządzania ryzykiem, jest dość niska. Mimo rosnącej popularności koncepcji ERM zdecydowana mniejszość badanych przedsiębiorstw prezentuje nowoczesną, proaktywną postawę wobec ryzyka, wdrażając bardziej efektywne systemy zintegrowanego zarządzania ryzykiem.

Uzyskane wyniki badań skłaniają do poszukiwania przyczyn dość niskiej świadomości ryzyka wśród większości polskich spółek. Bez wątpienia konieczne są dalsze, szerzej zakrojone badania dotyczące wdrażania i stosowania systemów zarządzania ryzykiem przez polskie przedsiębiorstwa, a także wpływu zarządzania ryzykiem na ich wyniki. Niezbędna jest również szersza popularyzacja koncepcji ERM, stosowanych metod i narzędzi oraz zwiększenie świadomości konieczności zarządzania ryzykiem.

\section{Literatura}

1. Adamska A. (2009), Ryzyko w działalności przedsiębiorstwa - podstawowe zagadnienia, [w:] Fierla A. (red.), Ryzyko w działalności przedsiębiorstw. Wybrane aspekty, Oficyna Wydawnicza SGH, Warszawa, s. 11-21.

2. Aon Polska (2013), Zarządzanie ryzykiem i ubezpieczeniami w firmach w Polsce. Raport Aon Polska 2013/2014, http://www.aon.com/poland/attachments/risk/AON_Raport_20132014.pdf (dostęp: 20.12.2016).

3. Bromiley P., McShane M., Nair A., Rustambekov E. (2015), Enterprise Risk Management: Review, Critique and Research Directions, „Long Range Planning”, Vol. 48, Issue 4, s. 265-276. DOI: 10.1016/j.lrp.2014.07.005

4. COSO (2004), Enterprise Risk Management Integrated Framework. Executive Summary, Committee of Sponsoring Organizations of the Treadway Commission, https://www.coso.org/ Documents/COSO-ERM-Executive-Summary.pdf (dostęp: 21.06.2017).

5. GPW (2016), Dobre praktyki spółek notowanych na GPW 2016, https://static.gpw.pl/ pub/files/PDF/RG/DPSN2016__GPW.pdf (dostęp: 21.06.2017).

6. ISO Guide 73:2009 (2009), Risk Management - Vocabulary.

7. ISO/IEC 31010:2009 (2009), Risk Management - Risk Assessment Techniques.

8. Kasiewicz S. (2011), Ocena stanu zarządzania ryzykiem w polskich firmach na podstawie wyników badań, [w:] Kasiewicz S. (red.), Zarządzanie zintegrowanym ryzykiem przedsiębiorstwa w Polsce, Wolters Kluwer, Warszawa, s. 154-172.

9. Kasiewicz S., Kurkliński L., Świerżewski Ł., Pasywne podejście do zarządzania ryzykiem, https://www.hbrp.pl/b/pasywne-podejscie-do-zarzadzania-ryzykiem/1D7wMooL3 (dostęp: 20.12.2016).

10. Korombel A. (2013), Apetyt na ryzyko w zarządzaniu przedsiębiorstwami, Wydawnictwo Politechniki Częstochowskiej, Częstochowa.

11. Krysiak Z. (2011), Silna kultura zarządzania ryzykiem jako cecha nowoczesnych organizacji, „E-mentor”, nr 2(39), s. 24-33.

12. Lam J. (2014), Enterprise Risk Management. From Incentives to Controls, John Wiley \& Sons, New Jersey.

13. Malinowska U. (2011), Charakterystyka kluczowych koncepcji zarządzania ryzykiem w przedsiębiorstwie, [w:] Kasiewicz S. (red.), Zarządzanie zintegrowanym ryzykiem przedsiębiorstwa w Polsce, Wolters Kluwer, Warszawa, s. 63-79. 
14. Monahan G. (2008), Enterprise Risk Management. A Methodology for Achieving Strategic Objectives, John Wiley \& Sons, New Jersey.

15. Sasin R. (2011), Ewolucja koncepcji ERM, [w:] Kasiewicz S. (red.), Zarządzanie zintegrowanym ryzykiem przedsiębiorstwa w Polsce, Wolters Kluwer, Warszawa, s. 98-113.

16. Suchecka J., Nieszporska S. (2015), Koncepcja ryzyka w kontekście funkcji użyteczności, „Zeszyty Naukowe Politechniki Częstochowskiej. Zarządzanie”, nr 19, s. 103-115.

\title{
CHARACTERISTIC OF ENTERPRISE RISK MANAGEMENT SYSTEMS USED BY THE BIGGEST POLISH LISTED COMPANIES
}

\begin{abstract}
The article presents the results of the analysis of risk management systems used by the biggest polish listed companies, with particular emphasis on companies with implemented modern Enterprise Risk Management (ERM) systems. The study was conducted based on the analysis of the information on risk management, published by companies listed on WIG20 and mWIG40 in their 2015 annual reports and it was divided into two stages. The first stage consisted in overall analysis of financial statements of all chosen companies. The aim was to determine the degree of maturity of presented risk management approaches. On this basis enterprises were divided into two groups: companies with implemented ERM systems and firms, that manage risk in the traditional way (silo). The second stage of the study consisted in detailed analysis of the information published by companies using ERM, in order to compare the characteristics of analyzed systems with predetermined characteristics, that modern ERM systems should have.
\end{abstract}

Keywords: ERM, enterprise risk management, risk, risk management system, uncertainty 